\title{
HOW TO IMPROVE THE SITUATION IN A „DIFFICULT" LABOUR MARKET: AN EXAMPLE OF THE FORMER STATE-OWNED AGRICULTURAL FARM COMMUNES IN BRANIEWO DISTRICT OF POLAND
}

Roman Kisiel ${ }^{1}$, Professor; Joanna Zielinska-Szczepkowska ${ }^{2}$, PhD

${ }_{1,2}$ University of Warmia and Mazury in Olsztyn, Faculty of Economic Sciences, Department of Economic and Regional Policy

\begin{abstract}
Contemporary scientific concepts coincide with the claim that one of the major factors determining the development of countries and regions is the development of local units. Most definitions of socio-economic development emphasise the significance of human capital in developing this phenomenon. Braniewo District, with an rate of unemployment at a level of $\mathbf{2 2 . 2} \%$, is ranked first in Warminsko-Mazurskie Voivodeship, and is among the highest in Poland. A significant percentage of the unemployed (including the long-term unemployed) live in rural areas in former state-owned farm localities. Unemployment in rural areas is a separate socio-economic problem that requires specific remedies and actions, especially with regard to the activation of former stateowned farm areas. This study analysed selected factors shaping the local labour market in Braniewo District. To achieve the main aim, the identification of the economic and labour market potential of the population inhabiting selected communes of Braniewo District was required. This enabled the formulation of initial recommendations regarding the ways of stimulating the human capital in the "difficult" labour market. The research methods applied in the study include a deductive study of relevant literature, reports, statistical analyses and a qualitative study involving direct interviews with the authorities of the communes of the analysed area as well as a survey conducted among 224 inhabitants of flats from the resources of former state-owned agricultural farm real estate. The established diagnosis and conducted analysis of social consequences of the ownership changes introduced in the agricultural sector by the Agricultural Property Agency in Braniewo District enabled an assessment of the changes occurring in former state-owned farm localities, and their effects on the inhabitants of the analysed communes.
\end{abstract}

Key words labour market, former state-owned farm areas, systemic transformation, unemployment. JEL code: J01; j88.

\section{Introduction}

The systemic transformation in Poland, initiated in 1989, resulted inter alia in the liquidation of state-owned agricultural farms (Panstwowe Gospodarstwo Rolne, PGR) (The Act, 1991). The aim of restructuring and distributing the assets of the Treasury (including PGRs) was to improve the effectiveness of farming and to make better use of the State assets (Wedrowska, Zapotoczna, 2004). It was assumed that the task was simple and effective. Unfortunately, economic and social consequences appeared to be very serious, as they resulted inter alia from the inadequate solution of the human problem. The scale of the problem is evidenced by figures. In Poland, almost $32 \%$ of privatised, previously state-owned enterprises, were PGRs. Almost 3.8 million ha of land, which accounted for over $45.3 \%$ of the rural area of the country, were subject to restructuring and privatisation. The area was inhabited by $38.3 \%$ of the rural population in Poland. The transformation of the State agricultural sector directly affected approx. 460 thousand of PGR employees whose number, along with their families, amounted to almost 2 million people. In 1991, former state-owned agricultural farm families inhabited 6,000 residential communities (Rynki pracy..., 2008). Consequently, the process of liquidation, restructuring and ownership changes in the PGR resources contributed to the emergence of the phenomenon of mass structural unemployment excluding a large proportion of inhabitants of former state-owner agricultural farm communes from the labour market. The consequence of occupational exclusion was the progressive marginalisation of these 
communities, which also resulted in social exclusion of not only the former PGR employees but also of subsequent generations of their families (Marks-Bielska, 2005; Gajowiak, 2013; Michalewska-Pawlak, 2010; Tarkowska, 2000; Hartvigsen, 2014; Kisiel, Marks-Bielska, 2017).

The economic, social and spatial consequences of the transformation of the State agricultural sector are most noticeable in rural areas in the so-called "former state-owned farm" voivodeships, e.g. Warminsko-Mazurskie Voivodeship. There is No doubt that they particularly concern these districts and communes in which PGRs used to be located. In terms of the number of the unemployed, Braniewo District is the highest in Warminsko-Mazurskie and one of the highest in Poland. The aim of this study is to analyse selected factors shaping the labour market. Former state-owned farm communes of Braniewo District were used as an example. In order to achieve this aim, it was necessary to identify the economic and labour market potential of the population inhabiting the analysed area. This enabled the formulation of initial recommendations as regards the ways of stimulating the human capital, and thus of an answer to the research question being the title of this paper: how to improve the situation in a "difficult" labour market in former state-owned agricultural farm communes of Braniewo District.

The reason for undertaking the study was the need to diagnose and analyse social and economic consequences of the ownership changes introduced in the agricultural sector by the Agricultural Property Agency in Braniewo District. The study encompassed all communes located within the administrative boundaries of the district (i.e. Braniewo, Frombork, Lelkowo, Pieniezno, Płoskinia, and Wilczeta) with a particular focus on rural areas. Given the diversity and availability of sources, the study used data from the years:

- 2004-2017 - as regards the unemployment rate evolution;

- 1974-2018 - as regards the study of relevant literature;

- 2018 (July-November) - as regards surveys, direct interviews, field inspections, and the discussion panel.

Both quantitative data retrieved from the public statistics system (Statistics Poland's Local Data Bank) and data aggregated by the District Employment Office in Braniewo and the offices of the following communes: Braniewo, Frombork, Lelkowo, Pieniezno, Płoskinia and Wilczeta were used in the study. Moreover, information collected from surveys (400 questionnaires were distributed with the return rate of $56 \%$ ), direct interviews, and field inspections was used. In each of the analysed communes, a discussion panel was organised in which local government representatives, Commune Office employees, and inhabitants of the analysed units participated. The article forms the first part of scientific considerations due to the limited volume.

\section{Research results and discussion}

Warminsko-Mazurskie Voivodeship is the fourth largest region in Poland with an area of over $24,000 \mathrm{~km}^{2}$ and a population of $1,442,242$, of which women account for $51.0 \%$ and men for $49.0 \%$. Since the beginning of the systemic transformation in Poland, one of the region's fundamental problems to be solved has been structural unemployment resulting from the liquidation of Stateowned Agricultural Farms which, at the end of 1980 s, covered almost $50 \%$ of the total area of agricultural land in the Warmia and Mazury region (Niedzielski E., 2017). Of all the communes forming Warminsko-Mazurskie Voivodeship, Braniewo District was at the forefront of districts with over $50 \%$ of agricultural land under the control of PGRs (Wojewodztwo Olsztyńskie..., 1974). 
Braniewo District, with a rate of unemployment of $22.2 \%$ (as at 31.12.2017), is currently the highest in the Warminsko-Mazurskie Voivodeship, and is among the highest in Poland in terms of the number of the unemployed. The rate of unemployed in the corresponding period in WarminskoMazurskie Voivodeship amounted to $11.7 \%$, and in Poland it was $6.6 \%$ (Table 1 ).

The unemployment rate in Warminsko-Mazurskie Voivodeship: December 2016, November 2017, and December 2017

\begin{tabular}{|c|c|c|c|c|}
\hline Territory? & December 2016 & November 2017 & December 2017 & $\begin{array}{c}\text { Increase/decrease } \\
4-2\end{array}$ \\
\hline Poland & 8.2 & 6.5 & 6.6 & -1.6 \\
\hline $\begin{array}{l}\text { Warminsko-Mazurskie } \\
\text { Voivodeship }\end{array}$ & 14.2 & 11.5 & 11.7 & -2.5 \\
\hline Elblag Subregion & 17.6 & 13.9 & 14.2 & -3.4 \\
\hline Braniewo District & 25.3 & 21.4 & 22.2 & -3.1 \\
\hline Działdowo District & 19.1 & 16.5 & 16.9 & -2.2 \\
\hline Elblag District & 20.8 & 17.9 & 18.0 & -2.8 \\
\hline Iława District & 6.0 & 4.7 & 4.9 & -1.1 \\
\hline Nowe Miasto District & 10.6 & 8.2 & 8.5 & -2.1 \\
\hline Ostroda District & 14.7 & 12.2 & 12.3 & -2.4 \\
\hline The city of Elblag & 11.3 & 9.1 & 9.0 & -2.3 \\
\hline
\end{tabular}

Source: author's calculations based on Statistics Poland's data for years 2017 and 2018.

The problem of high unemployment rate has been observed in the analysed district for many years. Fig. 1 presents the evolution of the unemployment rate in Braniewo District in the years 2004-2017 compared to the voivodeship and Poland.

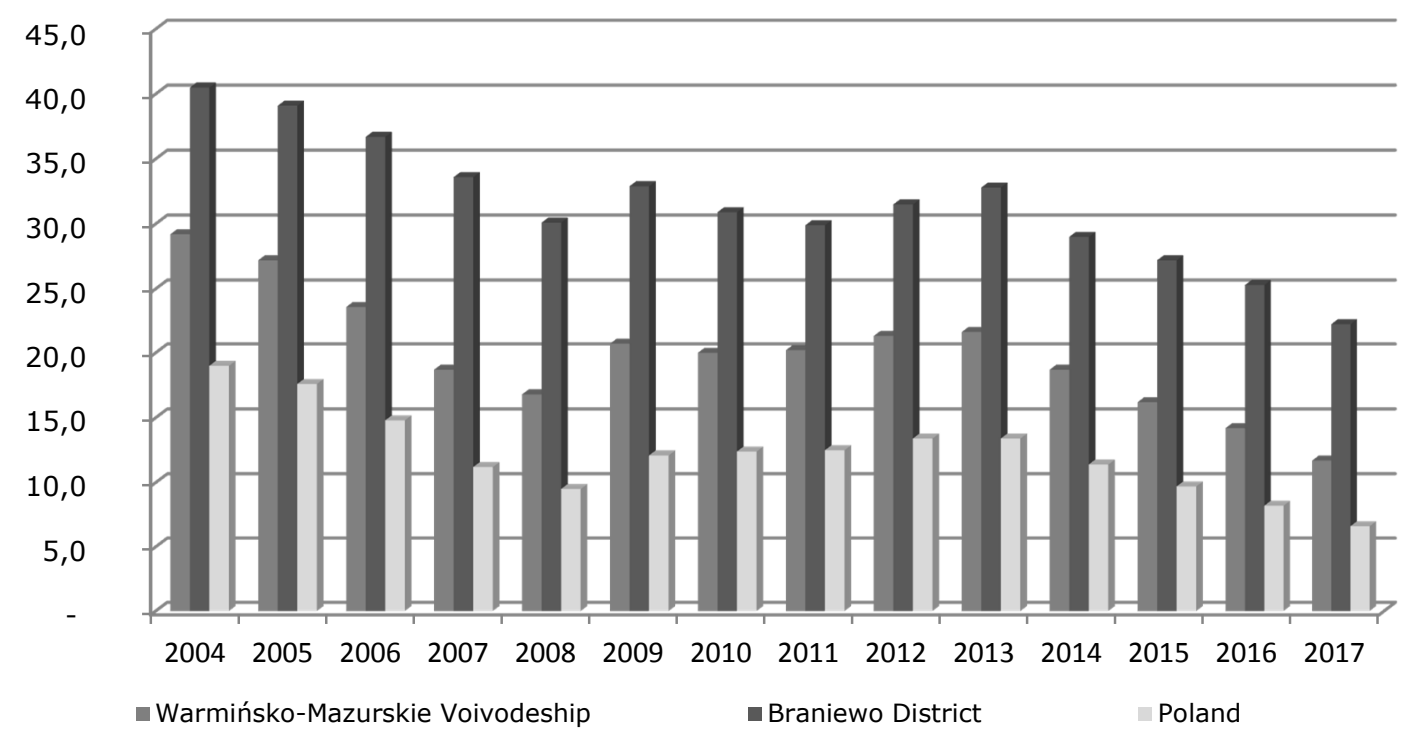

Source: author's calculations based on Statistics Poland's data

Fig. 1. The rate of registered unemployment in Braniewo District in the years 2004-2017

According to the presented data, in 2004, after Poland's accession to the EU, with the average unemployment rate in Poland of $19.0 \%$, an index more than twice as high (40.5\%) was noted in Braniewo District, which was very unfavourable even compared to Warminsko-Mazurskie Voivodeship with the unemployment rate of $29.2 \%$. Since 2014, a gradual and progressive decrease in the 
number of the unemployed has been observed both at the level of Braniewo District and of the entire voivodeship and Poland. An important role in this process is served by labour market institutions, including District Employment Offices, which, in accordance with the Act on the promotion of employment and labour market institutions, determine the so-called support profiles (I, II and III) based on the diagnosis of the situation in the voivodeship labour market. Depending on the unemployed person's classification into a specific profile, career counsellors prepare for them an individual plan of activation measures.

A significant percentage of the unemployed (including the long-term unemployed) live in rural areas. Unemployment in rural areas is a separate socio-economic problem that requires specific remedies and actions, especially with regard to the activation of former state-owned farm areas. The effects of unemployment should be considered under the conditions of local labour market typical of small towns such as Braniewo, Pieniezno, Frombork or specific former state-owned farm communities.

The problem of mass unemployment arose, as in the whole country, in 1991. Mass unemployment occurring after the liquidation of State Agricultural Farms (Panstwowe Gospodarstwo Rolne, PGR) was primarily due to the low level of human capital of these unemployed as well as maladjustment, in terms of qualifications and the mindset, to the emerging competitive labour market (Kopycinska, 2018). According to the District Employment Office's data, in Braniewo, at the end of 2017, almost a fourth of the total population were registered as unemployed. The surveys conducted among Commune Office employees and village leaders reveal that the district is poorly industrialised and lacks workplaces providing employment to a large number of people. In 2014, brewing production was relaunched at the Braniewo Brewery, which resulted in employment provided to almost 80 people. However, the labour market is too limited to offer employment to everyone willing and able to work, irrespective of their personal values, skills or education.

A great opportunity to improve the situation in the labour market was the introduction, in July 2012, of the Agreement on Local Border Traffic which, due to the convenient location of the town of Braniewo (two road crossing-points in Gronowo and Grzechotki), established potential conditions for economic development of the borderland between Poland and Russia (Zielinska-Szczepkowska, Zabielska, 2016). As shown by statistical data, local border traffic has contributed to an increase in tourism activity of Russians and Poles alike, which was often combined with purchases of goods and services in border localities. Throughout the nearly 4-year term of the Agreement on Local Border Traffic, almost $80 \%$ of foreigners crossed the eastern border of Poland for commercial and tourism purposes (Statistics Poland, 2014). Numerous border crossings performed by inhabitants of the Kaliningrad Oblast of the Russian Federation to do shopping in borderland shopping centres and grocery discounts during periods of increased traffic (before important Russian celebrations) contributed to an increase in incomes earned by entrepreneurs. In Braniewo District, new large surface stores with signboards in Russian language emerged, and their working hours were extended (sometimes they were open 24 hours a day including on Sundays and holidays). For the inhabitants of Polish borderland areas (including Braniewo District), facing the problems of high unemployment rate, the Agreement on Local Border Traffic was a great opportunity to improve their financial situation. The entry into force of visa-free traffic and the development of shopping tourism enhanced economic activity and contributed to the development of small businesses. It should be stressed that for a number of Poles inhabiting the borderland between Poland and Russia, the so-called fuel tourism became a particularly popular form of activity due to large 
differences in fuel prices (Zielinska-Szczepkowska, Zabielska, Kisiel, 2018). The turning point was the suspension of the Agreement on 4 July 2016 by the Polish side, with the Russian side retaliating in kind. Since then, border traffic between Poland and the Kaliningrad Oblast has been taking place exclusively on a visa basis, which, unfortunately, has had a very negative impact on the possibility for further development of entrepreneurship in the analysed district.

In today's reality, when assessing the economic situation of Braniewo District, it should be stated that it fails to make full use of the development opportunities arising from the borderland location. A certain number of inhabitants solve their financial problems by means of smuggling and illegal trade. However, such a way of earning a living is only a way of survival and not of ensuring a decent life.

Table 2 presents the number of the registered unemployed in particular communes of Braniewo District at the end of 2017.

Table 2

The registered unemployed by communes (as at 31 December 2017)

\begin{tabular}{|c|c|c|c|c|c|c|c|}
\hline \multirow[b]{2}{*}{ Commune } & \multirow[b]{2}{*}{$\begin{array}{c}\text { Number } \\
\text { of } \\
\text { people } \\
\text { in total }\end{array}$} & \multicolumn{6}{|c|}{ of which: } \\
\hline & & women & $\begin{array}{c}\text { in a } \\
\text { particularly } \\
\text { difficult } \\
\text { situation in } \\
\text { the labour } \\
\text { market }\end{array}$ & $\begin{array}{l}\text { under } 30 \\
\text { years of } \\
\text { age }\end{array}$ & $\begin{array}{c}\text { including } \\
\text { under } 25 \\
\text { years of } \\
\text { age }\end{array}$ & $\begin{array}{l}\text { over } 50 \\
\text { years of } \\
\text { age }\end{array}$ & $\begin{array}{l}\text { the long- } \\
\text { term } \\
\text { unemployed }\end{array}$ \\
\hline $\begin{array}{l}\text { The town of } \\
\text { Braniewo }\end{array}$ & 791 & 445 & 682 & 221 & 102 & 206 & 458 \\
\hline $\begin{array}{l}\text { Braniewo } \\
\text { commune }\end{array}$ & 496 & 276 & 448 & 151 & 81 & 136 & 313 \\
\hline $\begin{array}{l}\text { The town and } \\
\text { commune of } \\
\text { Frombork }\end{array}$ & 214 & 124 & 192 & 60 & 27 & 53 & 139 \\
\hline $\begin{array}{l}\text { The town and } \\
\text { commune of } \\
\text { Pieniezno }\end{array}$ & 280 & 167 & 240 & 68 & 32 & 68 & 194 \\
\hline $\begin{array}{l}\text { Lelkowo } \\
\text { commune }\end{array}$ & 479 & 254 & 444 & 121 & 64 & 140 & 345 \\
\hline $\begin{array}{l}\text { Płoskinia } \\
\text { commune }\end{array}$ & 166 & 102 & 139 & 47 & 28 & 43 & 98 \\
\hline $\begin{array}{l}\text { Wilczeta } \\
\text { commune }\end{array}$ & 249 & 130 & 226 & 74 & 35 & 69 & 174 \\
\hline $\begin{array}{l}\text { Braniewo } \\
\text { District }\end{array}$ & 2675 & 1498 & 2371 & 742 & 369 & 715 & 1721 \\
\hline
\end{tabular}

Source: author's calculations based on Statistics Poland's data for years 2017 and 2018.

When analysing the structure of the unemployed in Braniewo District, it should be stressed that the great majority of registered people are those in a particular difficult situation in the labour market ( $88.63 \%$ of the total number of the unemployed). An important issue in labour market analysis is unemployment among young people under 30 years of age. At the end of 2017, the number of the registered unemployed aged under 30 years in the analysed district was 742, which accounted for as much as $27.74 \%$ of the total number of the unemployed. Almost a half of the above-mentioned people are young people under 25 years of age, often school graduates with No experience required by the employers, which results in a high unemployment rate in this age group.

A separate group that has been faced with the problem of unemployment is that of the elderly, including people over 50 years of age. Given the statistical data, the greatest number of the unemployed in this age group and among the long-term unemployed was noted in Lelkowo commune. A significant problem in the Braniewo labour market is the high percentage of the 50+ unemployed with No professional qualifications; according to the data of the Voivodeship Employment Office in 
Olsztyn, every third unemployed person (33.3\% of the total number of the registered ones) has No qualifications to practice any profession authenticated with a relevant diploma, certificate or other document.

During the survey conducted among the inhabitants of Braniewo District communes, they were asked inter alia to indicate the causes of unemployment within the district (Fig. 2).

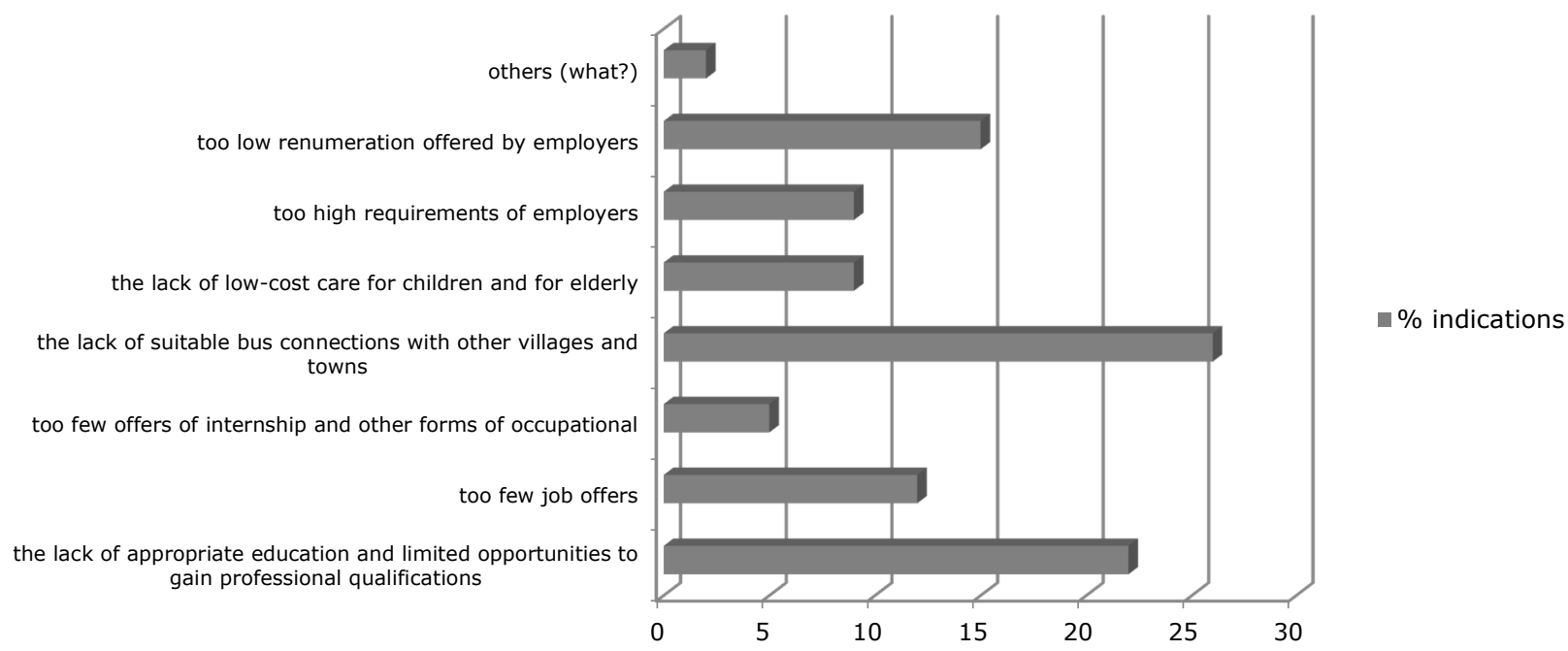

Source: author's calculations based on survey results $(N=226)$

Fig. 2. What are the causes of unemployment in Braniewo District?

The great majority of respondents indicated the lack of suitable bus connections with other localities and towns ( $26 \%$ of answers). The following answers were ranked second: the lack of appropriate education and limited opportunities to obtain professional qualifications, and too low employers' requirements ( 22 and $15 \%$ indications, respectively). For $12 \%$ of respondents, the high unemployment is due to the small number of job offers. Almost every tenth respondent believed that employers in the district had too high requirements, while the same number of women were of the opinion that an obstacle to taking up employment was the absence of low-cost care for children (nurseries, kindergartens) and the elderly (day care centres, retirement communities, etc.).

The consequences of long-term structural unemployment were also the topic of direct interviews with employees of communal social welfare centres granting social assistance benefits to the inhabitants of former State Agricultural Farms on a daily basis, as most people who lose their right to the unemployment benefit join the ranks of social assistance system beneficiaries. Officials report that the unemployed in a particularly difficult situation in labour market notice a deterioration in their mood, feel anxiety and distress, and suffer from depression. Unemployment has a devastating effect on their families, life plans of their members get disrupted and the safe existence of the family is at risk. Joblessness causes rapid degradation and exacerbates family's poverty. Unemployment is also a conflict-forming factor which exacerbates social ills such as alcohol abuse, excessive aggression and domestic violence. Parents' unemployment frequently implies, for children and young people, a change to and the limitation of plans for further education, lowering their professional aspirations, and the inhibition of the development of their skills and interests. Statistical data clearly show that unemployment increasingly affects young people, particularly those under 30 years of age. As regards the former state-owned agricultural farm localities, an additional factor contributing to the preservation of this unfavourable situation is a phenomenon known as the inheritance of unemployment. 
The fundamental problem of Braniewo District, strongly emphasised during discussion panels with commune representatives (commune heads and village leaders), is the lack of adequate road infrastructure and transport networks - not only between localities in the commune or district but also between districts and voivodeships. In their opinion, taking organised measures in this respect may contribute to a greater spatial mobility of inhabitants who are in this way provided with an opportunity to search for sources of income outside their immediate place of residence. As jobs are primarily created by leading regional centres, improved access to them via a well-developed transport network (including private carriers) should contribute to the improvement in access to major labour markets. This, in turn, may contribute to the improvement in living conditions of the analysed district inhabitants.

\section{Conclusions, proposals, recommendations}

Based on the conducted study, the following recommendations and proposals for action aimed at the improvement of the situation in this "difficult" labour market in Braniewo District were put forward:

1) as regards the institutions having both direct and indirect impact on the labour market: coordination of activities and exchange of information between institutions and organisations involved, both directly and indirectly, in solving problems associated with the labour market, such as: District Employment Office, local self-governments, employers' associations and representatives, the National Support Centre for Agriculture (KOWR); Organisation of profiled training sessions for the unemployed (corresponding to the demand for jobs in Braniewo District), offering internships and intervention works to help gain experience; cooperation with non-governmental organisations in the field of creating new jobs, ensuring conditions for creating new jobs (favourable investment climate).

2 ) as regards education: adjusting the vocational education profile to the requirements of local labour market; supporting schoolchildren in the professional pre-activation through meetings with career counsellors; initiating activities aimed at adjusting the education, including supplementary, to the needs of local labour market; promoting good and effective models for overcoming unemployment.

3) as regards support for former state-owned agricultural farm families: individual work with people and families affected by unemployment in order to help them develop responsibility for their own destiny and the skill of adapting to life in today's reality; providing children from the poorest families with scholarship assistance; protecting children against the effects of their parents' unemployment by the provision of basic school equipment, meals, and extracurricular activities; organisation of effective and low-cost care for small children of persons taking up employment and for the elderly and disabled (professional activation of people involved in family care); creation of subsidised work places for the provision of care services.

4) As regards transport accessibility: increasing the district inhabitants' mobility through investing in roads (promotion of the "I live in a village and commute to work in a town" lifestyle); developing a transport network with particular emphasis on the inter-district and intervoivodeship transport.

\section{Bibliography}

1. BDL (2004-2018). Bank of Local Data. Rynek pracy 2004-2018. Dane podgrup (Labour market 2004-2018. Subgroup data) Retrieved from: http/stat.gov.pl/bd/app/ (20.01.2018). 
2. Gajowiak, M. (2013). Deficyt kapitału społecznego na popegeerowskich obszarach jako bariera zrownowazonego rozwoju polskiej wsi (The deficit of social capital in former state-owned farm areas as a barrier to sustainable development of Poland's countryside). Folia Pomeranae Universitatis Technologiae Stetinensis: Oeconomica 299 (70), pp. 71-80.

3. Hartvigsen, M. (2014). Land reform and land fragmentation in Central and Eastern Europe. Land Use Policy 36 (2014), p. 330-341.

4. Kisiel, R., Marks-Bielska R. (2017). Transformations of the Polish agriculture. Russian Peasant Studies, 2 (3), p. 108-119.

5. Statistics Poland, Statistical Office in Rzeszow. (2014). Ruch graniczny oraz wydatki cudzoziemcow w Polsce i Polakow za granica w 2013 r. (Border traffic, foreigners' expenses in Poland and Poles' expenses abroad in 2013), The Centre of Transborder Areas Surveys and Statistics for Euroregions, Rzeszów.

6. Kopycinska, D. (2018). Popegeerowskie powiaty - prekariat w wojewodztwie zachodniopomorskim (Former state-owned farm districts - the precariat in Zachodniopomorskie Voivodeship). Studia i Prace WNEiZ US 51(3), pp. 185-196.

7. Marks-Bielska, R. (2005). Byli pracownicy PGR jako „przegrani” transformacji ustrojowej (Former StateOwned Agricultural Farm employees as the "losers" in the system transformation). Polityka Społeczna 7, pp. 9-12.

8. Michalewska-Pawlak, M. (2010). Mozliwosci i bariery rozwoju kapitału społecznego na obszarach wiejskich w Polsce (Possibilities and barriers to the development of social capital in rural areas in Poland) in: "Kapitał społeczny. Interpretacje, impresje, operacjonalizacja", M. Klimowicz, W. Bokajło (eds.). Warszawa, Wydaw. Fachowe CeDeWu.pl, pp. 185-202.

9. Niedzielski, E., Kisiel, R. (2017). Przekształcenia własnosciowe w rolnictwie - 25 lat historii i doswiadczeń (Ownership changes in agriculture -25 years of history and experience), Olsztyn, p. 5.

10. Rynki pracy na obszarach popegeerowskich (Labour markets in former state-owned agricultural farm areas), Report of the study (2008), Retrieved from: http://analizy.mpips.gov.pl/images/stories/publ_i_raporty/pgr.pdf

11. Tarkowska, E. (2000). Bieda popegeerowska (Post-state-owned agricultural farm poverty), In: E. Tarkowska (ed.), Zrozumiec biednego. O dawnej i obecnej biedzie $w$ Polsce (Understanding the poor. On the poverty of the past and present in Poland). Warszawa: The Institute of Philosophy and Sociology, Polish Academy of Sciences.

12. The Act (1991). Act of 19 October 1991 on the management of agricultural property of the State Treasury and on the revision of certain Acts. Journal of Laws of 1991, No 107, item 464.

13. The Act (2004). Act of 20 April 2004 on the promotion of employment and labour market institutions, Journal of Laws No 99, item 1001.

14. Wedrowska, E., Zapotoczna, M. (2004). Zastosowanie metod taksonomicznych do oceny efektywnosci zagospodarowania substancji mieszkaniowej po byłych ppgr (The application of taxonomic methods to assess the effectiveness of development of the former state-owned agricultural farm housing infrastructure) Wyd. AE in Wrocław, Prace Naukowe Nr 1023.

15. Wojewodztwo Olsztynskie. Monografia Ekonomiczno-Społeczna 1945 - 1969 (Olsztynskie Voivodeship. Economic and social monograph 1945 - 1969) (1974), Wojciech Kętrzynski Centre of Scientific Research in Olsztyn, The National Ossolinski Institute, Publishing House, p. 116.

16.Zapotoczna, M., Łaguna, D. (2018). Wpływ zmian zachodzących w pedestrianize wiejskiej na jakosc zycia mieszkancow w wybranych gminach wojewodztwa warminsko-mazurskiego - część I (The effects of changes occurring in the rural space on inhabitants' quality of life in selected communes of Warminsko-Mazurskie Voivodeship - Part 1), Infrastruktura i ekologia terenow wiejskich, 1(1), pp. 163-181.

17.Zielinska-Szczepkowska, J., Zabielska, I. (2016). Mały Ruch Graniczny z obwodem kaliningradzkim FR a rozwoj turystyki zakupowej (Local border traffic between Poland and the Kaliningrad Oblast of the Russian Federation and the development of shopping tourism). Zeszyty Naukowe Uniwersytetu Szczecinskiego, Ekonomiczne Problemy Turystyki 1 (3), pp. 349-362.

18.Zielinska-Szczepkowska, J., Zabielska, I., Kisiel, R. (2018). Turystyka transgraniczna - wybrane aspekty (Transborder tourism - selected aspects). Wydawnictwo UWM, Olsztyn, p. 119. 